\title{
Health equity critical to transforming system, says outgoing CMA president
}

I $\mathrm{n}$ her final address as president of the Canadian Medical Association, Dr. Anna Reid made an impassioned plea for the importance of improving the social determinants of health, even as she acknowledged increasing political pressure to cut costs to make medicare sustainable.

"We will be unable to sustain our health care system if we do not address these determinants," Reid told about 300 doctors and other health care professionals attending the CMA's General Council meeting in Calgary, Alberta on Aug. 20. "If governments want to bend the cost curve on health care spending as they say they do, one way to start is to look at the upstream factors in people's lives that make them sick."

"An estimated one in every five dollars spent on health is directly attributable to the social determinants of health," she stressed.

Social determinants of health, including poverty, lack of housing, limited access to care, addictions, inadequate attention to early childhood development and Aboriginal inequities, have been a focus of Reid's presidency, as has her insistence that doctors need to advocate for Canadians' broader health. The emergency physician from Yellowknife, Northwest Territories, has also urged physicians to look at improving access to their services, such as considering their hours, location and proximity to public transit.

Her final speech reflected many delegates' motions at the meeting that articulated the need for doctors and patients, not politicians, to determine what health care services are necessary and appro- priate in a cost-cutting climate. Some delegates also emphasized that if physician leaders don't make some of these decisions, they will find change forced upon them by governments.

example, ultrasounds for low-back pain - not only cost the health care system money, they may pose risks, Levinson told the meeting via an audio hook-up from Toronto.

"This is about physician engagement and leadership in the use of finite resources," said Levinson, chair of the Department of Medicine at the University of Toronto. "It's us helping ourselves practise evidence-based medicine."

Although one of the campaign's goal will be to reduce the estimated $30 \%$ of health care costs spent on overtreatment and overtesting, Levinson insisted it is not primarily focused on cost - an assertion Reid reiterated.

"We're engaged in this to ensure the focus remains on quality of care, not only costcutting," Reid said. That's a distinction provincial politicians, who need to balance their health care budgets, don't always understand, she added.

In the last days of Reid's term, she called for a national seniors' care strategy, including pharmacare, and made it clear she has already asked new federal Health Minister Rona Ambrose to champion the issue in the federal Cabinet.

"In private telephone conversations ...

To that end, the CMA will work with Dr. Wendy Levinson from the University of Toronto, Ontario as well as provincial medical associations, specialty associations, and consumer and patient groups to launch a public awareness campaign called Choosing Wisely Canada in April 2014. The campaign is designed to educate patients and doctors about potentially unnecessary and overprescribed tests and treatments. Some of those tests - for he [Ambrose] has told me that she plans to make seniors' care a priority," Reid told reporters at a press conference.

Throughout her presidency, Reid has been open about the way in which the stress and anxiety in her personal life are similar to those experienced by many other Canadians when it comes to seeking health care for themselves and their families. She almost resigned as incoming president when, shortly before she 
was to take on the job, her mother died suddenly of acute leukemia and Reid was left to care for her elderly father, who has dementia.

Reid was unable to move her father from Ontario to Yellowknife because of residency requirements in the territories that would have meant a three-month hospital stay before he could qualify for an assisted living placement. Reid opted instead to move to Ottawa with her father. At the time, he had already been waiting two years for an extended-care bed in Ontario.

In a moving tribute in her closing speech, Reid relayed the effects of that care-giving role on herself and her spouse, Linda Kalbun.

"The direct care for my father was a full-time job," said Reid, even though her father was in a private long-term care facility because no publicly funded beds were available. "The burden of that care fell to Linda. Linda was the bow-paddler on the most challenging whitewater trip of my life and I am deeply grateful to her."

The lack of portability of long-term care beds within Canada is among the issues many of Reid's former patients told her about when she was a family doctor in British Columbia. And the stress and difficulty she experienced in accessing care for her 93-year-old father are typical of the challenges that face other Canadians, she said.

"It reflects all the issues around seniors' care in Canada."

Reid, who received a standing ovation at the end of her speech, challenged doctors to continue to lead the search for solutions to improving health equity, which she said reflects patients' calls for action. "We can be, and we are, the drivers of change," Reid said. - Laura Eggertson, CMAJ

CMAJ 2013. DOI:10.1503/cmaj.109-4588 